\title{
Village Administration in Indonesia: A Socio-Political Corporation Formed by State
}

\author{
Chanif Nurcholis ${ }^{1}$, Sri Wahyu Krida Sakti ${ }^{2}$, Ace Sriati Rachman ${ }^{3}$ \\ ${ }^{1}$ Administration Department of Law, Social, and Political Sciences Faculty, Universitas Terbuka, Tangerang, Indonesia \\ ${ }^{2}$ Law Department of Law, Social, and Political Sciences Faculty, Universitas Terbuka, Tangerang, Indonesia \\ ${ }^{3}$ Communication Department of Law, Social, and Political Sciences Faculty, Universitas Terbuka, Tangerang, Indonesia \\ Email: hanif@ecampus.ut.ac.id, sriwahyu@ecampus.ut.ac.id, acesr@ecampus.ut.ac.id
}

How to cite this paper: Nurcholis, C., Sakti, S. W. K., \& Rachman, A. S. (2019). Village Administration in Indonesia: A Socio-Political Corporation Formed by State. Open Journal of Political Science, 9, 383-404.

https://doi.org/10.4236/ojps.2019.92021

Received: February 25, 2019

Accepted: April 20, 2019

Published: April 23, 2019

Copyright (c) 2019 by author(s) and Scientific Research Publishing Inc. This work is licensed under the Creative Commons Attribution International License (CC BY 4.0).

http://creativecommons.org/licenses/by/4.0/

\begin{abstract}
Village government is the lowest level administration in Indonesia. It is formed by law. However, a village head is not a government official and also village employees are not civil servants. The Village Government has authority to administer government affairs; nevertheless, the central government doesn't decentralize the government affairs to the Village. The organizational structure is like a municipal, consisting of a mayor and council; yet the mayor is not chief of local bureaucrats and the council is just a voluntary board that functions like a council. Such a fact is problematic, which raises the question regarding the legal status of village in the administration of the Republic of Indonesia. The study used a post-positivistic approach with a qualitative method. Jabon Mekar village, Bogor Regenstschap (Municipal), Banten Province was chosen as the locus of the study. The results conclude that the village administration is a pseudo local self-government. To that end, a village institution needs to become a public organization to comply with the Indonesia Constitution of 1945, in order to provide public services that would prosper the people.
\end{abstract}

\section{Keywords}

Village Government, Government Affairs, Pseudo Local Self-Government

\section{Introduction}

Villages in Java-Madura were firstly regulated under the Native Municipal Ordinance, namely Inlandsche Gemeente Ordonnantie 1906 (IGO, 1906), while the village outer islands of Java-Madura were regulated under Native Municipal Ordinance for Outer Islands, namely Inlandsche Gemeente Buitensgewesten 
Ordonnantie (IGO, 1906). Villages under IGO 1906 in relation with (juncto) IGOB 1938 were socio-political corporations under control of the State. Day (1904) and Furnivall $(1916,1956)$ stated that village administration ruled by IGO 1906 juncto IGOB 1938 is a kind of indirect rule (indirect bestuurd gebied) model. This village administration is presided by the district head as government officer that runs central government public service mission in local government. Angelino (1931: pp. 403-411) stated that village administration is an indigenous community institutional buraucracy under control of a "Regentsraad" (Council of Municipal) and a "Resident" (government official whom his job position is under the Dutch Colonial Governor and above Mayor or Regent).

Breman (1982: p. 196) stated that the village administration is a colonial bureaucratic creation. Specifically, the Javanese "desa"/"village" as a native municipal (inlandsche gemeente) is a European bureaucratic creation. Before the colonial era, a village was just a peasant community that did not have a government system. The Government then made it as a corporation as an instrument of cultivation policy, so called cultuurstelsel. Village heads were assigned to provide land and labour for mass-plantation under local head (regent or mayor) control. The village heads and local heads played acted as middlemen between the colonial rulers and the peasantry. Furnivall (1956: pp. 241-242) explained that the Village Act of 1906 was expressively designed for both to strengthen the village community bonding and to attune it to the modern world, to stimulate social growth, and to enable local officials to cope with their main function, which was to take care of public welfare. Niel (2003: p. 227) explained that the village administration is not a native local-self government, but rather that of a socio-political corporation formed by the colonial state.

After Indonesia's independence, villages were regulated under Article 18 of the 1945 Constitution. This article regulates large and small local self-governments. Based on Article 18, the Law No. 22 of 1948 sets up villages as a special local-self-government. The Law No. 22 of 1948 was amended by Law No. 1 of 1957. Under this law, a village is the third tier of local self-government. Law No. 1 of 1957 was amended by Law No. 18 of 1965 juncto Law No. 19 of 1965. Based on these laws, the village is a local self-government based on the customary law (adat law). Law No. 19 of 1965 was amended by Law No. 5 of 1979. Under this Law, the village is set up as a socio-political corporation under control of the State. Law No. 5 of 1979 was amended by Law No. 22 of 1999. Law No. 5 of 1979 was amended by Law No. 22 of 1999. Law No. 22 of 1999 was amended by Law No. 32 of 2004. Law No. 32 of 20041979 was amended by Law No. 23 of 2014 and Law No. 6 of 2014. Law No. 22 of 1999 juncto Law No. 32 of 2004 juncto Law No. 6 of 2014, the status of a village is a socio-political corporation similar to local self-government.

Without critical arguments, Widjaja (2003) concluded that a village under Law No. 22 of 1999 has a native, spherical, and intact autonomy. Widjaja simply follows the provisions of Law No. 22 of 1999 without logically reviewing it based 
on the 1945 Constitution Article 18 and its Explanation, and Article 18B paragraph (2). Native autonomy refers to rechtsgemeenschappen (law communities). After Indonesian independence, the 1945 Constitution Article 18 and its Explanation provide guidance to convert all existing law communities into special small local self-governments. Based on the legal perspective, IGO 1906 and IGOB 1938 were revoked by Law No. 19 of 1965, and that of Law No. 19 of 1965, all former customs administrations (law communities) were converted to local self-governments based on customary law (adat law).

Law No. 19 of 1965 was amended by Law No. 5 of 1979. Based on this Law, the status of a village is not a local self-government, but as a socio-political corporation-a variant of state corporatism (Schmitter, 1974). The village is an instrument of the central government to implement their political and economic policy. Village institution under this law was not regulated and arrenged as native autonomy. Law No. 5 of 1979 was amended by Law No. 22 of 1999 then Law No. 22 of 1999 amanded by Law No. 32 of 2004. Based on this Law, the village became a quasi-government (Ranggawidjaja, 2013). Nurcholis (2017) stated that the village under Law No. 5 of 1979 juncto Law No. 22 of 1999 juncto Law No. 32 of 2004 is pseudo government because it is not local self-government, not rechtsgemeenschapen (Vollenhoven, 1907; Haar, 2013); and not indigenous poeples (ILO Convention No. 169 of 1989; United Nations, 2007). If Widjaja equates the village as local self-government based on custom as stipulated by Law No. 19 of 1965, it is illogical because the village under Law No. 5 of 1979 juncto Law No. 22 of 1999 is not local self-government (United Nations, 1962; Muttalib \& Khan, 1983). Widjaja's thesis is difficult to be accepted since the arguments built do not follow deductive logic.

Syafrudin and Na'a (2010) explained that village administratation needs to be recognized by the State and given native autonomy. He equates village administration under Law No. 22 of 1999 juncto Law No. 32 of 2004 to adat rechtsgemeenschapen (adat of law communities). Eko et al. (2014) also equate village administration to adat rechtsgemeenschapen. Most scholars have had a colonial bias, for they still perceive that the village as adat rechtsgemeensc happen while in fact it has been set as a state agency under Law No. 5 of 1979 juncto Law No. 22 of 1999 juncto Law No. 32 of 2004. Having become an agent of the state, village is no longer adat rechtsgemeenschappen (Moniaga, 2010; Panggabean, 2011). According to Vollenhoven (1907), Haar (2013), and International Labor Organization Convention ILO Convention No. 169 of 1989, the term adat rechtsgemeenschappen is communities formed by indigenous people who borned, grown up, and developed as well as maintained their own-self institution.

According to Suparman (2012), the position of Village Head under Law No. 5 of 1979 juncto Law No. 22 of 1999 juncto Law No. 32 of 2004 juncto Law No. $6 / 2014$ is not a government officer, although he/she conducts the government's general affairs. The village head is not the head of the community and does not take care of the community's affairs. He/she simply implements higher govern- 
ment's affairs based on the legislation. Therefore, since the village head is not a government official, then the institution of village is actually not a governmental unit either. According to Nurcholis (2014), the village institution, which was created by New Order regime under the Law No. 5 of 1979 and which has been maintained until now, is pseudo government.

Based on this background, a deeper study needs to be conducted. The study aims to clarify the legal status of village administration measured by the theory of legislation and local government. The objects studied were villages as institution set up by New Order regime and Reformation regime under Law No. 5 of 1979 juncto Law No. 22 of 1999 juncto Law No. 32 of 2004 Juncto Law No. 6 of 2014.

\section{Scope of Study}

This study discussed the controversial administrative and legal issues over the village government arangement, that in this case Jabon Mekar Village was taken into account of a purposive sample. Jabon Mekar village is one of the villages in Parung Sub-Municipal (District), Bogor Municipal (Regenstschap/Kabupaten), West Java Province. Its teritorial area is 217,095 hectares, divided into two hamlets. The population at the end of 2018 was 9.586 inhabitants. Geographically, it is located approximately $40 \mathrm{~km}$ southwest of Jakarta, the capital city of the Republic of Indonesia.

The study areas covered the questionable legal-status of the village government institution as government institution and its impact on its bureaucratic system. The study scope included dicussion of consequences of Indonesia as a unitary state that its bureaucratic system adheres to a presidential government system, that relates to a system of separation and decentralization of power at the central to regional levels. This study down the line explained on the lowest dimensional level of Indonesia government bureaucratic system in relation to the linkage between the logical issues of public administration with the prevailing law politics on local government. The village government status by far has been placed as a state institution that is not entirely a formal government ("PseudoGovernment" or "State Corporatism") which has an impact on the slowing down of the development process.

\section{Literature Review}

Breman (1982) explained that the village administration in Indonesia was created by the colonial rulers. Basically, it was just a community of peasants. Netherlandsh Indie converted it into a corporation of communities (rechtsgemeensc happen). This policy was considered as an effort made by the Dutch colonial government to control villagers and their land.

Ball (1982: p. 115) explained that Raffles (the British Colonial Governor General) replaced the antiquated and illeberal institutions of semi-feudal Regents with an "enlightened" European style of administration. Raffles regarded the village as the lowest-level of unitary community living area of 
Javanese society, and as subordinates of the Regents (Mayor) that rule villages through each of their chiefs, witch both of them acting as intermediaries who canalize villagers to deal directly with the "government". Ball (1982: p. 169) stated that after the Dutch ruled over Indonesia for the second turn, in 1818 the Commissioners published the Government Regulations. They mantained Raffles's administrative framework, that hierachically, the areal division of the Dutch government structural authority under the Governor-General consisted of Residency (renamed later becoming Province), of District (renamed later becoming Regenciy/Municipal), of Divisions (renamed later becoming District/Sub-Ordinat of Municipal), and of Village.

Since Indonesia's independence, the Indonesian constitution has been perfected several times, but is still called the Constitution of the State of Indonesia Republic 1945 (The Constitution of 1945, before and after the amendment). Before the Constitution was amended for the first time, it only regulated the local self-government, but after the amendment, it emphasized the local self-government and indigenous peoples' matters. On Article 18B Paragraph (2) of Constitution of 1945 (after the amandment) stipulates that the State shall recognize and respect to adat rechtsgemeenschap (law of adat communities) who are still surviving and developing in its form in accordance with the development of a civilized society, and whose administration is in accordance with the principles of the Unitary State of the Republic of Indonesia. Adat rechtsgemeenschap is an indigenous community that set itself up based on customary law. According to Vollenhoven (1907: p. 43), rechtsgemeenschappen (law communities) are constituent corporate units of an organized indigenous society which derive their distinct, legal autonomy in domestic affairs from the fact that each has a) its discrete representative authority, and $b$ ) its discrete communal property (beschikkingsrecht), especially land, over which they exercise control. Rahman (2011) states that adat rechtsgemeenschap is the same as indigenous peoples. According to Haar (2013), adat rechtsgemeenschap consist of groups, arranged in an orderly and fixed manner, having self-governing mechanism, and owning material and immaterial wealth. Furthermore, Haar (2013) explained that adat rechtsgemeenschap have the all-sacred objects as their hereditary heritage treasures, visible kinship, heritage, lineage from members of the community derived from a common ancestor, standard of conduct to do necessary activities as rechtspersoon (corporation), and constantly make decisions in the meetings as the crystallization of social reality. The decisions are supported by the members of the community and are carved in its social system. Asshiddiqqie (2006) described adat rechtsgemeenschap as referring to the sense of organic community, i.e. society composed within the framework of organizational life, mutually binding themselves for the sake of achieving common goals and managing social systems based on customary law.

According to the Explanation of Law No. 6 of 2014, a village is a mixed form between community and local self-government. This construct is unclear. Horton and Hunt (1984) explained that a community is a group of people who 
organize themselves naturally based on procedures and practices. The procedures and practices are then transformed into customs that are kept, maintained, and developed as social guidelines. The community forms independent institutions and is free from state intervention. The United Nations (1962) explained that local government is a national political subdivision, regulated by law and has substantial control over its local affairs, including the power to levy taxes or dismiss its officers for a particular purpose. The overall government body is selected or appointed locally. Hoessein (2002) explained that local government is a unit of local administration that has authority of rule-making (regeling) and rule-application (bestuur) over its local public interests based on its own initiative. In terms of public administration, each authority is commonly referred to as policy-making and policy-executing. Governing is an act of creating legal norms, which is applied publicly in concrete and individual situations (beschikking), or a material act in the form of services and development of a particular object. Local government is formed due to matters of decentralization. Rondinelli \& Cheema (1983) explained that decentralization is the transfer of planning, decision-making, or administrative authority from the central government to its field organizations, local administrative units, semi-autonomous and parastatal organizations, local government, or non-government organizations. Stoker (1991) affirmed that local government consists of elected local government and non-elected local government. Elected local government consists of counties/regions and districts while non-elected local government consists of the central government's arms-length agency, local authority implementation agency, public/private partnership organization, user organizations, inter-governmental forums and boards. A village government under the Law No. 6 of 2014 is not a community, since it is established by the State. A village government is also not local self-government, since it is not an official State body in obtaining the decentralization of governmental affairs from the central government and executing the authority to regulate and manage the decentralized governmental affairs.

Turner and Hulme (1997) explained that administrative reform is a means to make an administrative system to be a more effective instrument to accommodate social change, and a better instrument to bring about political equality, social justice, and economic growth. Administration reform strategy is done through organizational restructuring, participation, human resource development, accountability, and a mix of public and private services.

\section{Methodology}

The ambiguous legal status of village government in the administration system of Republic of Indonesia has raised the question "What is the legal status of village in Indonesia administration?". To answer the question, a study with qualitative method was conducted. The data was obtained through field observations, legislation study, documents study, in-depth interviews and focus group discussion (FGD). Field observations were conducted by using observation guidelines 
in Jabon Mekar village, Bogor, West Java Province, to find out the general pattern of village officials work with their stakeholders. Field observation was carried out in the form of non-participatory observations on various daily activities carried out by the village officials, through observing the implementation of daily and periodical work on the 4 village principal task areas, such as public services, general development, community empowerment, and community fostering. The village was chosen due to several reasons, such as its status is considered a village (rural characteristics) but geographically, demographically, socially, and culturally has urban characteristics. The study of legislation was also conducted by reviewing the manuscript of IGO 1906, IGOB 1938, Law No. 22 of 1948, Law No. 19 of 1965, Law No. 5 of 1979, Law No. 22 of 1999, Law No. 32 of 2004, Law No. 6 of 2014, and their implementation. This study of village governance legislation was carried out by using statute and conceptual approaches. While the analytical technique used was content analysis and synchronisity analysis of the articles in the legislation that govern village governance. Documents review was conducted by examining scholarly articles concerning the village issues and the official annual report of village government. This document study was carried out by using document review guidelines applied on various important official manuscripts covering primary legal materials (organic legislation), secondary legal materials in the form of academic texts legislation, official manuscripts of village legal research reports, and tertiary legal materials covering legal-lexicon and various mass media legal-content related to village government arrangements. In-depth interviews were conducted by using interview guidelines for the purpose of obtaining detailed and comprehensive information by interviewing key-persons at Jabon Mekar village who were considered having dominant influence and control over running the village government administration, such as the head of the village, the village secretary, the members of the Village Consultative Body. The relevant experts on Government Studies and on Constitutional Law were also involved in depth-interview process. FGDs were also held by using FGD guidelines, involving a number of nasional government administration experts, practitioners/consultants and village government bureaucrats to discussing specific village governance arrangement issues. Specifically, the participants of whom were the members of the Special Committee of the Bill on Village from the House of People's Representatives, the officials of the National Institute of Public Administration $(L A N)$, the Secretary General of Indonesian Village Government Association, the Regional Secretary of Tangerang Regenstschap, and the Head of Development Planning Agency of Karawang Regenstschap. The final stage was qualitative data analysis.

\section{Results and Discussion}

\section{Organizational Structure}

The Organizational Structure and Work Procedure (OSWP) of Jabon Mekar Village situated in West Java Indonesia can be exposed as follows: the village 
head is the leader. The village secretary is the head of staff consisting of six heads of village affairs: 1) Head of Government Affairs; 2) Head of Development Affairs; 3) Head of Financial Affairs; 4) Head of Public Affairs; 5) Head of Administration Affairs; and 6) Head of General Affairs. In addition, the village head is also assisted by regional and technical implementers. The regional implementing element consists of two hamlet heads and two technical implementers, namely: the Assistant of Marital Registrar (AMR or P3N) and the Community Protection Officers (CPO or Linmas).

The juridical status of village officials can be categorized as non-government employees, this is due to the absence of a legal basis governing village officials as part of civil servants. However, in some other village offices the village secretary job-position is held by the appointed public servants. They receive an honorarium from Bogor Regenstschap of IDR_150,000 (USD_11.27) per month, cashed out every three months. Because they are not civil servants, only non-permanent officers, then they can leave at any time or be replaced without having employment rights. In the current situation, the provision of village chief succession is taking place every eight years, and the involvement of village office employees is also changing which are often filled with new recruited officials. The case occurs when the village head is replaced by a new village head. In most villages in Bogor Regenstschap there is a habit of "leaving in droves" ("bedol-desa"), meaning that the incumbent village officials are replaced with the new recruited ones by a new village head soon after the incumbent village head steps down. The new recruited village officials appointed by the new village head were mostly those who supported the new village head during the local elections.

According to Law No. 6 of 2014, village institutions should have a have a Village Representative like Council $(B P D) . B P D$ has the task to create village regulation together with the village head, arrange the annual budgeting, and channel people's aspirations. BPD members come from the head of Neighbourhood Association $(R T)$, Communityhood Association $(R W)$ and public figures. $B P D$ member election procedures, functions and tasks, and its working mechanism are based on the regulations set by formal legislation, not based on the customary law.

The organizational structure of Jabon Mekar village is similar to the organizational structure of the municipal (regenstschap/kabupaten), which consists of the "council" $(B P D)$ and the village head. Jabon Mekar village is like a small form of regenstschap/kabupaten government institution. However, its status, functions, duties, and the working procedure are very different. The village head is not a government official like a regent or mayor (Suparman, 2012). The village officials are also not civil servants like regentschap/kabupaten bureaucrats. BPD is also not a real professional council, but a deliberation board that is both amateur and voluntary in membership, because it does not have secretariat facilities, civil servant support, office, and institutional infrastructures like regenstschap/ $k$ abupaten council $(D P R D)$. The village head and its subordinates are also not entitled to receive a fixed salary per month like any other regular government 
officials as civil servant. Their job is not to make policy on decentralized governmental affairs, but make policy on community affairs. BPD members are not political party members who were elected through general elections like members of a council. The BPD also does not conduct political oversight to the village government like any common normal council. Stoker (1991) states that this form of government structure is thus excluded from local government variants. The village government thus cannot be equated with the counties/regions, the field administration, the central government's arms-length agency, local authority implementation agency, public/private partnership organization, user organizations, inter-governmental forums, and joint-boards.

In accordance with Law No. 6 of 2014, village government office should oversees four authorities: 1) the authority based on the rights of natives; 2) the authority based on local scale; 3 ) the authority assigned by the superior government; and 4) other authority assigned by the superior in accordance with the provisions of government legislation. However, the village government of Jabon Mekar only oversees the $3 \mathrm{rd}$ and $4^{\text {th }}$ authorities. It does not hold the first authority, which is authority under the right of natives, and the second authority, which is the authority to regulate and manage the village affairs of Jabon Mekar. Jabon Mekar village does not hold the first and second authorities because it has no business coming from native and local-scale village affairs. Both authorities actually refer to the recognition of authority owned by rechtsgemeenschappen (law communities) as proposed by Vollenhoven (1907). Soepomo in (Yamin, 1971: p. 310) state that rechtsgemeenschappen is having the same meaning with volksgemeinschaften (popular community). In the case of the village as rechtsgemeenschappen, the village by itself holds the right of natives to organize village-scale affairs, based on customary law. Thus, when Jabon Mekar village and all the rest of the villages in Indonesia become a state agency, then consequently they are no longer entitled to hold the right of natives in organizing the village-scale affairs. The villages only hold authority from their superior government. Thus, when a village is constructed as rechtsgemeenschappen or indigenous peoples as stipulated by Law No. 6 of 2014, then it is contrary to customary law.

In affirmation of the incompatibility with the customary law, there is other evidence in the appointment of village heads. The village head is elected directly by the people. Candidates register themselves to the village-head election committee formed by BPD, without going through a political party like the Mayor (Regent or Bupati). People then elect the competing candidates. The candidate who gets the most votes is appointed as the village head and sworn in by the Mayor (Bupati or Regent). The procedure for village-head election and village heads appointment is setled in legislation, not based on customary law, and so is the rest of the procedure for the appointment of village officials. Everything is based on the state-law. If so, then viewing a village as adat rechtsgemeenschap (indigenous peoples) is seriously mistaken, since one of the main characteristics of indigenous peoples living law is that the head of the community is elected and appointed based on customary law, not by state-law as oppose to "Legal-Pluralism" 
(Vollenhoven, 1907; Haar, 2013; Asshiddiqqie, 2010).

Likewise, the model of a village-head election is not in accordance with the appointment of the head of local self-government. In the local self-government entity, the appointment of the head of the local executive is performed by direct election or by the council as a permanent independent body, not as an ad hoc-committee. The candidates are proposed by political parties or registered independently. Village-head elections are conducted directly. The election organizer is an ad hoc-committee. In this case, political parties are not involved in the village head appointment.

\section{Village Government Income}

Village government revenue is derived from the village owned resources, the results of self-help and community participation, the results of inter-institutional mutual cooperation, the local tax and retribution, the financial assistance from the central government, provincial government and regenstschap/municipal government, and a grant from the regenstschap (self-help returns). The Village Owned Revenue is derived from charges to its residents who request any service of issuing official certificate. Residents requesting a cover letter to obtain an identity card (ID or " $K T P$ "), land certificate, building permit (IMB), and letter of land transfer are charged between IDR50,000 and 100,000 (USD_3.75 - 7.51). The results of community participation and mutual-cooperation in social development-so-called community self-help ("Gotong-Royong")—may be regarded as a social justification through the use of persons with forced labor in rural infrastructure development for reasons of institutional income interests. Tax-sharing and regional retribution come from the levy of Land and Building Tax (LBT or "PBB") collection. Allocation of village funds comes from the Bogor Regenstschap/Kabupaten annual budget, from the balancing funds obtained from the State Budget. The Fund of National Community Empowerment Program (NCEP or "PNPM") comes from the central government to build rural infrastructure and economic empowerment of the people. The Budget consists of indirect spending, subsidies, grants expenditure, direct expenditure, spending on goods and services, capital expenditures and unexpected expenditures.

In Jabon Mekar village fiscal year of 2013, the village income mainly came from four resources, namely: 1) IDR_494,733,000 (USD_37,197) from levies (50\% of the total village income); 2) IDR_272,840,371 (USD_20,514) from the Bogor Regenstschap (the central and provincial) (28\% of the total village income); 3) IDR_145,000,000 (USD_10,902) from other regenstschap governments (12\% of the total village income); and 4) IDR_100,000,000 (USD_7518) from grants and donors ( $10 \%$ of the total village income).

The above financing model is derived from the tradition of the Islamic Mataram kingdom, passed down through the Dutch colonial government (Suroyo, 2000). In the Mataram Kingdom era, the village institution had to pay for itself. The main village revenue resources were collected from its communal land, its people who paid tribute to the ruler when requesting services, and its residents who were put into forced labour (heerendiensten) to work for village 
infrastructure maintenance and development. Jabon Mekar village institution no longer has communal land. Hence, it relies only on charges for public services provided and the deployment of forced labour (heerendiensten), such as community participation in working together ("gotong royong") for the cleanliness of the environment, maintenance of village infrastructure, or other village social agendas governed by the village head.

According to the United Nations (1962) and Muttalib \& Khan (1983), the revenue resources of local self-government are mainly amassed from local taxes, not levies and labour based on tradition. Thus, when viewed from its source of revenue, Jabon Mekar village then could be excluded from being so-called local-self-government. Law No. 6 of 2014 explains that a village by definition is a kind of mix between a self-governing community and local self-government. Perhaps what is meant by self-governing community in this context is that village is given authority to charge for public services and to impose forced labour, the heerendientsen. If this assumption is correct, then a village under Law No. 6 of 2014 has the same construct of villages in the culturstelsel colonial era (1830-1870) in which people were obliged to provide labour to the rulers in stages and pay charges to the head of the community for services rendered (Suroyo, 2000).

The revenue from the Central Government in the form of PNPM (National Project of Community Development/NPCD) fund of IDR 100,000,000 (USD 7.518) is not a transfer fund from the state budget to the Village Treasury Unit, but rather a project fund directly planned and controlled by the Central Government. The central government does not decentralize the State Budget to the village through the scheme of block grants. Thus, the village cannot use the fund in accordance with its local policy. This shows that a village is not a local self-government since one of the characteristics of local self-government is giving funds from the central government as block-grants (Muttalib \& Khan, 1983). With the allocation of funds from the Central Government as block grants, then the village can create a policy to set and execute it in accordance with its local interests (Hoessein, 2002).

\section{Activities Conducted by Village Government}

Routine activities undertaken by Village Government include: 1) submitting a security report to the sub-regenstschap/kabupaten office (kecamatan); 2) sending a demographic data report to the sub-regenstschap/kabupaten office (kecamatan); and 3) collecting the Land and Building Tax from residents. On a daily basis, a village office staff member is given the task of delivering a security report to the sub-regenstschap office (kecamatan). At the beginning of the month, the village secretary compiles a demographic report consisting of birth rate, mortality rate, and residence-move data for the sub-district office. Annually, a village staff member collects the Land and Building Tax from its residents/taxpayers, the results of which are deposited in the sub-district office.

The public services provided by the village office of Jabon Mekar are to issue a cover letter to their residents applying to get official documents such as: 1) identity card (ID or “ $K T P^{\prime}$ ); 2) family card (FC or “ $K K$ ”); 3) Land Title Deed (Land 
Certificate); 4) building permits (BP or " $I M B$ "); 5) a letter of unemployment; 6) a letter of marriage-divorce-reconciliation; and 7) a letter of poverty statement.

Residents who are applying for the papers first have to report to the head of the Neighborhood Association (NA or “ $R T$ ”), who later issues a cover letter. The applicants then request the signature of the head of the community association (CA or “ $R W^{\prime \prime)}$. After obtaining the signature, the applicant needs to go to the village office. The village head then issues a cover letter to be submitted to the sub-municipal office to obtain the signatures of Sub-Regenstschap Head (“Camat"). To apply for ID and CA, the applicant then submits the signed letter to the Department of Civil Records and Population Registration of Bogor Regenstschap/Kabupaten who will then issue the ID and CA to be handed over to the applicant through the Sub-Municipal Office and the Village Office. To request a land certificate, the applicant should bring the letter to the Bogor Field Administration Land Office of Ministry of Land and Agrarian Affairs, which later issues the requested land certificate. To request a letter of Job-Seeking, the applicant brings the proposition letter to the Department of Labor Office of Bogor Regenstschap/Kabupaten who will then issue the certificate of unemployment. To request a certificate of marriage-reconciliation-divorce, the applicant brings the cover letter to the Religion Affairs Office (RAO/“ $K U A$ ”), the field administration of Ministery of Religion Affairs. RAO then authorizes the intended marriage-divorce-reconciliation document. To request the letter of poverty statement, the applicant is supposed to bring the cover letter to the state hospital to get a medical fee waiver or submits it to social services to get subsidies from the government. Therefore, the village office is only an intermediate office. It is not a one-stop-serving-office providing final services to the public. The village offices providing services related to the official documents required by the residents are actually those which (providing services) belong to the central ministries. Thus, a village government is not a local self-government entity. It is only an intermediary serving the superior government.

Activities associated with the provision of public goods include services for pregnant and breastfeeding women, and children under five years old. The types of activities are weighing the children, providing milk and nutritional aid, and providing medical aid to mothers and children. Other activities cover providing information about the welfare of the family and providing training on domesticity and home industries for women. These activities are intended for women in order to help them to take care of their house better and develop small-scale domestic enterprises to improve the local economy. These activities are coordinated by Family Welfare Programs (FWP or " $P K K$ ”), which are headed by the spouse of the village head.

An activity related to development is building rural roads. Village road construction is funded by NPCD. NPCD funds come from the central government. The village government is required to raise the funds by way of labor exertion, or community work whose result is counted as a numerical fund, which means economic oriented in currency or in commercial way instead of village character 
building. The fund is given to the village through an ad-hoc body formed by the central government, in which the funding mechanism is posted on the central, provincial, district, sub-district and village government office website and notice-board with expectation to work in escalating public transparancy and reducing gratification. In this mechanism, the village does not regulate and manage the fund autonomously. The village only receives NPCD projects, which are planned and budgeted by the central government, and the implementation is managed by an ad hoc-body whose members are villagers who are also appointed by the central government.

The village government does not perform public activities and public services consisting of the provision of public goods, the development demand for peoples economic growth, and the accomplishment of protective activities. Village governments do not provide public goods but only mediate the provision of public goods. Village governments also do not do any development, since the development through the NPCD scheme is entirely under the control of the central government. Village governments only implement it. Village governments do not regulate and manage public affairs in accordance with their interests, whereas the authority to regulate (regeling) and administer (bestuur) is the main characteristic of local self-government (Hoessein, 2002). In addition, village government offices are naturally not involved in activities purportedly derived from their original ("originaire") or indigenous rights. Thus, in this case Jabon Mekar village as the lowest local government institution does not have the characteristics of indigenous peoples at all.

One thing that is unique about the Jabon Mekar village government office and other similar villages, is that they submit their work as state-formed civil institutions. However, these village government office task and function have been hardly accomplished by most village offices, because the village government offices does not have a working unit capable of executing policy implementation and most village offices have been operated by underskilled officials. Village government officials consist of one village secretariat staff and three other technical implementers of whom have no clear task and function. Services to pregnant women, lactating women, and children under five years old are left to the women's organization of Family Welfare Programs (PWP or PKK), presided over by the wife of the village head. The planning and implementation of small-scale development are submitted to the organization of Village Community Resilience Council (VCRC or LKMD). The collection of demographic data is handed over to a civilian organization namely NA and CA. Community empowerment programs are submitted to the organization of Institute for Community Empowerment (ICE or " $L P M$ "). Village security programs are handed over to the organization of Civil Defence (CD or Hansip) and People Defence (PD or Hanra), a civil organization run by soldiers.

According to Kurasawa (1993), the phenomenon explained above is a governance model based on mobilization and control. This model was implemented by the Japanese military government when they occupied Indonesia (1942-1945). 
During the Japanese occupation, with the intention of mobilizing the villagers to win the Greater East Asia War, the Japanese government invader established civil organizations that were used as a mobilization tool, such as: $K u$ (village), Aza (community association), and Tonarigumi (neighbourhood association). In addition, there were also other institutions, e.g.: Heiho (army assistants), Keibodan (police assistants), Seinendan (youth front), and Fujingkai (women's front) in the village. Later on, the New Order political regime led by a former Japan-educated officer replicated the model of the village administration, which continues until the present day (Nurcholis, 2017). Civic organizations formed by Colonial Japan only changed their nomenclature in the Soeharto era: $K u$ into Desa (village), tonarigumi into NA (Neighborhood Association or “ $R T$ ”), aza into CA (Communityhood Association or " $R W$ ”), heiho into Civil Defence ("Hansip"), Keibodan into People's Security ("Kamra”), fujingkai into Family Welfare Development (FWD or “ $P K K^{\prime}$ ), and Seinendan into Youth Organization (“KarangTaruna”).

The Status of Village Government

Jabon Mekar village and all villages alike in Indonesia are regulated by Law No. 6 of 2014. According to Article 1 Paragraph (1), a village shall mean a village and traditional village or called by other names, here in after called "Village", is a unity of legal community that has borders, is authorized to regulate and administer governmental affairs, the interests of the local community based on public initiatives, has the right of native and/or traditional rights that are recognized and respected in the system of government in the Republic of Indonesia.

By definition, a village is supposed to be a local self-government because it has the authority to regulate (regeling) and administer (bestuur) government affairs (Hoessein, 2002). However, the definition has become meaningless since the central government does not decentralize governmental affairs to the Village (Nurcholis, 2014; Nurcholis, 2017). According to Rondinelli \& Cheema (1983), the main characteristic of local government is the transfer of authority, which includes planning, decision-making, and administrative authority from the central government to its organizations, local administrative units, semi-autonomous and parastatal organizations, local government, or non-government organization. Jabon Mekar village and all villages alike in Indonesia do not receive the transfer of these powers, and thus do not regulate and administer governmental affairs. Jabon Mekar village and all villages alike in Indonesia only implement the tasks of superior government in the form of NPCD projects, facilitating maternal and child health services, reporting demographic data, legitimizing application of identity cards, family cards and all other certificates, and facilitating community empowerment programs.

Sutiyo and Lall (2017) explained that villages have traditional decentralization. It refers to Law No. 6 of 2014. Theoretically, the concept of traditional decentralization does not exist. Humes (1991) only explained about the traditional local government, which refers to tradisional government or tradisional monarchy. On the other hand, Angelino (1931: p. 403) stated that village administration is 
indigenous commune values laden, which means that the logical foundation of village administration is not based on formal and logical western philosophy as a modern system of government public service to operate, but merely more motivated by holy values, dedication, sincerity, and community to operate public service and development. Village administration is not local government, but is supposed to be self-governed indigenous commune under the control of Regenstschapraad (Municipal Council) and the "Resident" (government official whom his job position is under the Dutch Colonial Governor and above Mayor or Regent).

According to Stoker (1991: pp. 30-66), local government consists of elected local government and non-elected local government. Elected local government consists of counties/regions and districts, while non-elected local government consists of central government's arms-length agency, local authority implementing agency, public/private partnership organization, user organizations, inter-governmental forums and joint-boards. Jabon Mekar village is not included in both categories of local government.

In its "Explanation" of the Indonesia Constitution, Law No. 6 of 2014 is derived from Article 18B Paragraph (2) of the 1945 Constitution which regulates the indigenous peoples. According to Sudiyat (2010: p. 142) and Ter Haar, (2013: p. 6), indigenous peoples are a unified community based on regional singularity, whose organization is based on tradition, living in the social atmosphere, and have a body that regulates the governance affairs of the community who are authoritative in the neighborhood and adhered by all members. Haar (2013) stated that legal traditional communities express themselves in chiefs and their kin who make decisions in meetings as a crystallization of social reality. The decisions are supported by members of the community and inscribed in the social system. It is used to maintain the law and to resolve disputes. Vollenhoven (1907: p. 43; Sudiyat, 2010: p. 139) described adat rechtsgemeenschap or indigenous peoples as a unified community that has authority in the establishment, implementation, and development of the law. In the meantime, what he put forward as a society of law in his description of Javanese-Centred Custom Law is "a society created by its own", such as Bumiputera Company/Native-People Company, Bumiputra Association, the Order of Christian Bumiputra. The United Nations (2007) cited the Martinez Cobo Study that defines indigenous peoples as indigenous communities, peoples, and nations who have a historical continuity with pre-invasion and pre-colonial societies that have developed in their territories and consider themselves as distinct from other sectors of society that are now prevailing in those teritories as parts of that indigenous community. Indigenous peoples as communities are largely non-dominant sectors of society and are determined to preserve, develop, and transmit their customary values to the future generations as legacy of their ancestral territories, and their ethnic identity, as basis of their continuing existence in accordance with their own cultural patterns, social institutions and legal system.

Asshiddiqqie (2006) said that indigenous people legal unity refers to an or- 
ganic society that functions through its governmental organization as an instrument of the indigenous peoples. Thus, the indigenous people legal unity is a public entity that regulates the life of the community using the tool of customary law. The customary law as a tool consists of community organizations, right to land, debts law, institutional foundations, private law, kinship law, marriage law, inheritance law, and criminal law, all of which are original of themselves (Haar, 2013). If the social tool like village government administration is a creation of the state power, then it is not original as a traditional law community unit but formal legal community unit.

The institutional profile of Jabon Mekar village, such as its organizational structure, function, and mechanism of action, apparently governed by the State through legislation, does not function through customary law. Its government officials do not reflect the members of indigenous peoples but rather state-formed organization committee. The designation of village head and subordinateofficers are not based on customary law but based on positive law (state law). Village institutional administration functioning as a social-tool is not an instrument of customary governance, but a state government function. The village affairs organized are not based on the customary values and concerns, but rather on government bureaucratic affairs from the superior government. The only customary characteristic applied is the revenue collection function from the fee charged to the residents who need public services and labour exertion, such as community work for rural infrastructures. Here Figure 1, portrays the Jabon Mekar Village Government Organizational Structure that delineates modern organizational structure rather than the indigenous one.

Based on various theoretical explanations, such as from Sudiyat (2010), Haar (2013), Vollenhoven (1907), Asshiddiqqie (2006), Rahman (2011), and the ILO Convention No. 169 of 1989, then the case of Jabon Mekar village administration could justifiably be excluded from indigenous peoples' characteristic parameters,

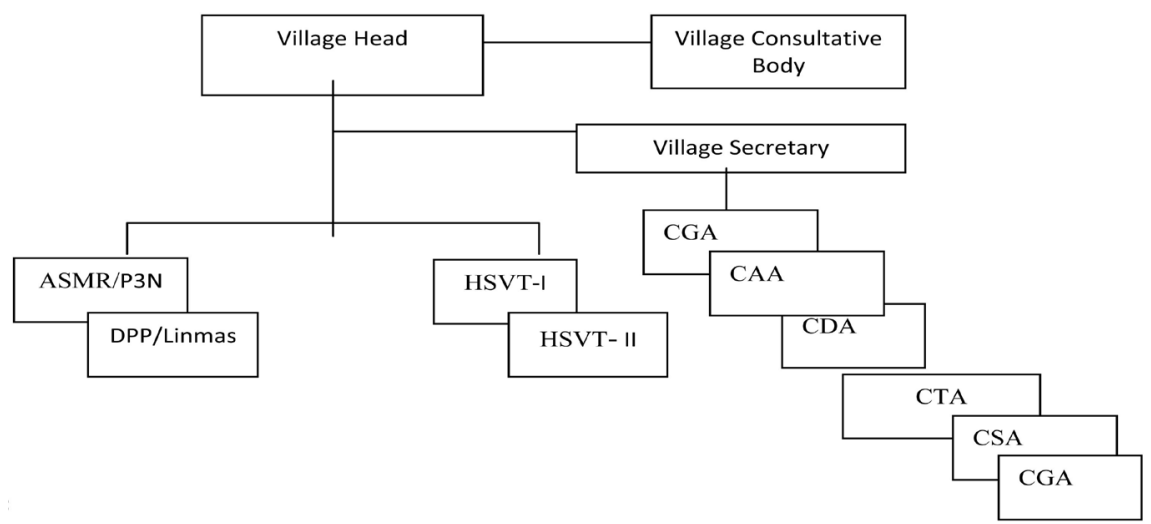

Figure 1. The Organizational Structure of Jabon Mekar Village Government Source: Jabon Mekar Village Monograph Wall-Board. Notes: CGA: Chairman of Government Affairs; CAA: Chairman of Administrative Affairs; CDA: Chairman of Development Affairs; CTA: Chairman of Treasury Affairs; CSA: Chairman of Social Affairs; CGA: Chairman of General Affairs; HSVT: Heads of Smaller Village Teritory (Dusun); ASMR: The Assisstance-Staff of Marriage Registry; DPP: The Detachement of People Protection. 
it is because: 1) The village governmental organization is established by the Govern social atmosphere and has governance bodies which are authoritative throughout the region; 2) The village legal basis is the government which conducts governance activities as state law, not a law made by the community chiefs and its Kinship norms in meetings; 3) The village authority belonged to Jabon Mekar village office is not the authority established, implemented and supervised by the community itself, but an authority determined by the State through legislation; 4) The village does not have a system of customary law which governs the life of its people; 5) The village does not have customary inheritance treasures both material and immaterial; and 6) The village does not have customary land.

Rasyid (1997), an expert on regional administration, explained that a village is not a unit of government buraucracy but a self-governing community. Rasyid's opinion is mistaken because a village institution by rules is not a community but a state organ established under the law. This is because an institution that has activities of self-governing community is called a community (Horton \& Hunt, 1984). Jabon Mekar village government is not an instrument of rural community. Horton and Hunt (1984: p. 446) further explained that one of the characteristics of community is one whose members can act collectively in an organized manner. Among other things, Jabon Mekar village government is not a tool to administer the interests of the community, but the State's tool to administer government affairs. All organizational devices in Jabon Mekar are not treated by the community independently, but set-up by the State through legislation.

The village institutional model in Jabon Mekar and 74,956 other villages was established by the State under Law No. 5 of 1979 juncto Law No. 22 of 1999 juncto Law No. 32 of 2004 juncto Law No. 6 of 2014. These laws deny the village as indigenous peoples or rechtsgemeenschap. Through the order of subsequent law namely Law No. 5 of 1979 Juncto Law No. 22 of 1999 Juncto Law No. 32 of 2004 Juncto Law No. 6 of 2014, a fundamental change occurs over the village institutional legal status. Village administration, originally as a form of traditional governance (Java and Madura) and indigenous peoples (outside Java and Madura), has been turned into state governance. All customs governance in Java and Madura and indigenous peoples outside Java and Madura have been removed and replaced with a new governance model. The new model has been described as the "Administration-Village" ("Desa Administrasi") as opposed to "Customary-Village" ("desa adat").

Thus, the model of village bureaucratic institution today, when viewed from a historical perspective, is a replication of the village administration model during the Japanese occupation under the law so-called Osamu Seirei No. 27 of 1942, Osamu Seirei No. 7 of 1944, and its implementing regulations. The Japanese government removed the customary governance model; in the same era a new village institution was formed under the nomenclature of $K u$ (village). Under the $\mathrm{Ku}$, Aza (community association) and Tonarigumi (neighborhood association) 
were formed. Ku was led by Kuchoo (village head) and assisted by Juru Tulis (village secretary), five Mandor (Foremen), a village policeman, and an Amir (religious official). Kuchoo was elected directly for a four-year period of service on each term of appointed cycle (Aziz, 1955; Kurasawa, 1993; Nurcholis, 2017).

Asshiddiqqie (2015) explained that a village institution needs to be adequately regulated. To that end, "village government" should be institutionalized as a separate legal entity to obtain its legal status as an autonomous legal subject in the traffic of public law and private law. Referring to Turner and Hulme's (1997) postulation, village government institutional restructuring is required. The restructuring includes the clarification of the village institutional legalstatus in the state administration system whereas as Indonesia is a unitary state, the organizational structure is based on the theory of local self-government, and the delegation of functions based on the delegated government affairs. The administrative reform must also be intended to make village administration be more participatory, to make village government officals be more competent and professional, to make the system of government be more accountable, and to make the village institution be more capable of providing effective public services that improve people's welfare.

The overall description of Jabon Mekar village profile above can be succinctly figured in Table 1.

\section{Conclusion}

Based on the discussion above, the village government regulated by Law No. 6 of 2014, in particular Article 1-95, is justifiably a pseudo local self-government entity under the regenstschap/municipal administration. It is justified in pursuant of

Table 1. Institutional profile of Jabon Mekar Village, Bogor Municipal (Regenschap/Kabupaten), West Java Province, Indonesia.

\begin{tabular}{|c|c|c|c|c|c|}
\hline $\begin{array}{c}\text { Various } \\
\text { Institutional Status }\end{array}$ & $\begin{array}{l}\text { Organizational } \\
\text { Element }\end{array}$ & Main Task \& Function & Governmental Model & Type of Village & Basic Authority \\
\hline 1 & 2 & 3 & 4 & 5 & 6 \\
\hline $\begin{array}{c}\text { Pseudo } \\
\text { Government }\end{array}$ & $\begin{array}{ll}\text { o } & \text { Structure: } \\
\text { o } & \text { Village Head; } \\
\text { o } & \text { Village Secretary; } \\
\text { o } & \text { Head of Village Affairs. }\end{array}$ & $\begin{array}{c}\text { Mandatory of } \\
\text { upper government }\end{array}$ & $\begin{array}{l}\text { Socio-political } \\
\text { organization } \\
\text { formed by State }\end{array}$ & $\begin{array}{l}\text { Semiofficial } \\
\text { government }\end{array}$ & $\begin{array}{l}\text { Attributed } \\
\text { authority }\end{array}$ \\
\hline $\begin{array}{c}\text { State } \\
\text { Corporatism }\end{array}$ & $\begin{array}{ll}\text { o } & \text { Structure: } \\
\text { o } & \text { Village Head; } \\
\text { o } & \text { Village Secretary; } \\
\text { o } & \text { Head of Village Affairs. }\end{array}$ & $\begin{array}{c}\text { Mandatory of } \\
\text { Upper Government }\end{array}$ & $\begin{array}{l}\text { Socio-political } \\
\text { organization } \\
\text { formed by State }\end{array}$ & $\begin{array}{l}\text { Semiofficial } \\
\text { government }\end{array}$ & $\begin{array}{l}\text { Attributed } \\
\text { authority }\end{array}$ \\
\hline $\begin{array}{l}\text { Organization } \\
\text { Structure }\end{array}$ & $\begin{array}{ll}\text { o } & \text { Village Head; } \\
\text { o } & \text { Village Secretary; } \\
\text { o } & \text { Head of Village Affairs. }\end{array}$ & $\begin{array}{l}\text { Medicare of Upper } \\
\text { Government by } \\
\text { village community }\end{array}$ & Semi-Government & $\begin{array}{l}\text { Semi } \\
\text { mayor-council }\end{array}$ & $\begin{array}{l}\text { Attributed } \\
\text { authority }\end{array}$ \\
\hline $\begin{array}{c}\text { Village } \\
\text { Consultative Body }\end{array}$ & Like Council Municipal. & $\begin{array}{l}\text { Make basic policy } \\
\text { with village head }\end{array}$ & $\begin{array}{c}\text { Quasi local } \\
\text { self-government }\end{array}$ & $\begin{array}{l}\text { Semi } \\
\text { council }\end{array}$ & $\begin{array}{l}\text { Attributed } \\
\text { authority }\end{array}$ \\
\hline $\begin{array}{l}\text { Position of } \\
\text { Hierrarchy }\end{array}$ & $\begin{array}{l}\text { Under control of Municipal } \\
\text { (Regentschap). }\end{array}$ & $\begin{array}{c}\text { Mandatory of } \\
\text { upper government }\end{array}$ & State corporatism & $\begin{array}{l}\text { Semiofficial } \\
\text { government }\end{array}$ & $\begin{array}{l}\text { Attributed } \\
\text { authority }\end{array}$ \\
\hline
\end{tabular}


Article 18B Paragraph (2) of the 1945 Constitution regarding the indigenous peoples. Nevertheless, villages alone are not indigenous peoples. The village is a new institution established by the State based on laws and regulations. It is not an elected or non-elected local government mechanism because it is not a formal government unit in the region formed by the central government based on the principle of decentralization. It is not a community based institutional function because its authority, organizational structure, functions and duties, and its mechanism of action are governed by the State through legislation and it does not organize the affairs of its community but administers the governance affairs given from its superior government.

Therefore, village instituion needs to be reformed into a public organization (Turner \& Hulme, 1997) in accordance with the norms of the 1945 Constitution. The 1945 Constitution (before the amendment) mandated that indigenous peoples or adat rechtsgemeenschap may be converted into a special/asymmetric small local self-government, whereas the 1945 Constitution (after the amendment) mandates that the existence adat rechtsgemeenschap or indigenous peoples may be recognized and respected by the State. Under the administrative norm, villages need to be thoroughly studied and classified into three categories: 1) as indigenous peoples who are still surviving; 2) as indigenous peoples who are hardly surviving only faded away so that their customs can be revived; 3) as indigenous peoples who are completely dead that their customs do not exist anymore in the society (Asshiddiqqie, 2006). In regard to the first category, the Government supposedly recognizes and respects them (Article 18B Paragraph 2 of the 1945 Constitution; ILO Convention No. 169 of 1989; United Nations, 2007). In regard to the second category, the Government should revitalize them so that the already faded out customary laws can be revived and finally recognized and respected (Article 18B Paragraph 2 of the 1945 Constitution, ILO Convention No. 169 of 1989; United Nation, 2007). In regard to the third category, the Government should make two policies: 1) the urbanized village should be incorporated into the current government administration system of the regenstschap/municipal governments; and 2) the villages which have rural characteristics are combined with each other and turned into custom-based autonomous regions as asymmetrical local governments (Article 18B Paragraph (1) of 1945 Constitution and Indonesia People Assembly Decree No. IV of 2000).

\section{Acknowledgements}

We would like to express our gratitude to the head of Jabon Mekar Village, the Head of The State Administration Agency, Mr. Budiman Sujatmiko as a member of the House of Representatives, and other key-informants. We also like to expandour thankful to Mr. Ryas Rasyid as a member of the President's Consideration Board.

\section{Conflicts of Interest}

There is no conflicts of interest among the writers regarding the publication of 
this paper.

\section{References}

Angelino De Kat, A. D. A. (1931). Colonial Policy The Dutch East Indies (Volume II). The Hague: Martinus Nijhoff.

Asshiddiqqie, J. (2006). Hukum Acara Pengujian Undang-Undang (Legal Procedure of Legislation-Testing). Jakarta: Konstitusi Press.

Asshiddiqqie, J. (2010). Perkembangan dan Konsolidasi Lembaga Negara Pasca Reformasi [Development and Consolidation of Post-Reformation State Institutions]. Jakarta: Sinar Grafika.

Asshiddiqqie, J. (2015). Gagasan Konstitusi Sosial (The Thought of Social Constitution). Jakarta: LP3ES.

Aziz, M. A. (1955). Japan’s Colonialism and Indonesia. Hague: The Hague Nijhoft.

Ball, J. (1982). Indonesia Legal History. Sydney: Oughtershaw Press.

Breman, J. (1982). The Village on Java and the Early-Colonial State. The Journal of Peasant Studies, 9, 189-240.

Day, C. (1904). The Policy and Administration of the Dutch in Java. London: Macmillan.

Eko, S. et al. (2014). Desa Membangun Indonesia [Village Builds Indonesia]. Yogyakarta: Forum Pengembangan Pembaharuan Desa.

Furnivall, J. S. (1916). Netherlands India: A Study of Plural Economy. Amsterdam: B.M. Israel BV.

Furnivall, J. S. (1956). Colonial Policy and Practice. A Comparative Study of Burma and Netherlands India. New York: New York University Press.

Haar, T. B. (2013). Asas-Asas dan Susunan Hukum Adat (The Principles and the Order of Customary Law). Jakarta: Balai Pustaka.

Hoessein, B. (2002). Kebijakan Desentralisasi (The Policy of Decentralization), Jurnal Administrasi Negara (Vol. 2, pp. 5-26). Jakarta: Yayasan Inovasi Pemerintahan Daerah.

Horton, P. B., \& Hunt, C. L. (1984). Sociology. Tokyo: McGraw-Hill.

Humes, I.V.S. (1991). Local Governance and National Power. London: IULA.

IGO Inlandsche Gemeente Ordonnantie (1906). Himpunan Peraturan Perundang-undangan Republik Indonesia. Tata Negara-Perdata-Dagang-Pidana. Penerbit Ichtiar Baru Van Hoeve.

IGOB Inlandsche Gemeente Ordonnantie Buitengewesten (1938). Himpunan Peraturan Perundang-undangan Republik Indonesia. Tata Negara-Perdata-Dagang-Pidana. Penerbit Ichtiar Baru Van Hoeve.

ILO Convention No. 169 of 1989. International Labor Organization Convention. http://www.humanrights.se/wp-content/uploads/2012/01/C169-Indigenous-and-Tribal -Peoples-Convention.pdf

https://www.ilo.org/wcmsp5/groups/public/@ed_norm/@normes/documents/publicati on/wcms_118120.pdf

Indonesia People Assembly Decree No. IV of 2000. The Decree of People's Consultative Assembly of the Republic of Indonesia (MPR) No. IV/2000 on the Policy Recommendation on Regional Autonomy Implementation. Himpunan Peraturan Perundang-Undangan Republik Indonesia. Tata Negara-Perdata-Dagang-Pidana. Penerbit Ichtiar Baru Van Hoeve.

Kurasawa, A. (1993). Mobilisasi dan Kontrol (Mobilization and Control). Jakarta: Grasindo. 
Law No. 18 of 1965 Concerning Local Government. Himpunan Peraturan Perundang-undangan Republik Indonesia. Tata Negara-Perdata-Dagang-Pidana. Penerbit Ichtiar Baru Van Hoeve.

Law No. 19 of 1965 Concerning Village Administration (Desapraja). Himpunan Peraturan Perundang-undangan Republik Indonesia. Tata Negara-Perdata-Dagang-Pidana. Penerbit Ichtiar Baru Van Hoeve.

Law No. 22 of 1999 Concerning Local Government. Himpunan Peraturan Perundang-undangan Republik Indonesia. Tata Negara-Perdata-Dagang-Pidana. Penerbit Ichtiar Baru Van Hoeve.

Law No. 32 of 2004 Concerning Local Government. Himpunan Peraturan Perundang-undangan Republik Indonesia. Tata Negara-Perdata-Dagang-Pidana. Penerbit Ichtiar Baru Van Hoeve.

Law No. 5 of 1979 Concerning Village Government. Himpunan Peraturan Perundang-undangan Republik Indonesia. Tata Negara-Perdata-Dagang-Pidana. Penerbit Ichtiar Baru Van Hoeve.

Law No. 6 of 2014 Concerning Village.

Moniaga, S. (2010). Adat dalam Politik Indonesia (Custom in Indonesia Politics). Jakarta: Yayasan Pustaka Obor Indonesia.

Muttalib, M. A., \& Khan, M.A.A. (1983). Theory of Local Government. Jalandhar City: Sterling Publisher PVT Ltd.

Niel, R. V. (2003). Sistem Tanam Paksa di Jawa (The Cultivation System in Java). Jakarta: Pustaka LP3ES Indonesia.

Nurcholis, H. (2014). Undang-Undang Nomor 6 Tahun 2014 Tentang Desa Dilihat dari Pasal 18 B Ayat (2) UUD 1945 (Law Number 6/2014 on Village Seen from Article 18 B Paragraph (2) of the 1945 Constitution). Jurnal Masalah-Masalah Hukum, 43, 149-159.

Nurcholis, H. (2017). Pemerintah Desa: Unit Pemerintahan Semu dalam Sistem Pemerintahan Negara Kesatuan Republik Indonesia [Village Government: Pseudo Government Unit in the Unitary State of the Republic of Indonesia]. Jakarta: BeeMedia

Osamu Seirei No. 27 of 1942. Himpunan Peraturan Perundang-undangan Republik Indonesia. Tata Negara-Perdata-Dagang-Pidana. Penerbit Ichtiar Baru Van Hoeve.

Osamu Seirei No. 7 of 1944. Himpunan Peraturan Perundang-undangan Republik Indonesia. Tata Negara-Perdata-Dagang-Pidana. Penerbit Ichtiar Baru Van Hoeve.

Panggabean, H. (2011). Pemberdayaan Hak Masyarakat Hukum Adat (Empowerment of Indigenous People's Rights). Jakarta: Permata Aksara.

Rahman, I. N. (2011). Dasar Pertimbangan Yuridis Kedudukan Hukum (Legal Standing) Masyarakat Hukum Adat dalam Proses Pengujian Undang-Undang di Mahkamah Konstitusi (Basic Legal Consideration as Legal Standing of Costumary Law on the Legislation Testing Process in the Constitutional Court). Jurnal Konstitusi, 8, 767-802.

Ranggawidjaja, R. (2013). "Pasal 18B ayat (2)", dalam Abdurahman, A. dkk (ed), Satu Dasawarsa Perubahan UUD 1945 (Article 18B verse (2) in Abdurrahman, A. et al. (ed), One Decade of Change of 1945 Constitution). Bandung: Fakultas Hukum UNPAD-PSKN FH UNPAD.

Rasyid, R. M. (1997). Birokrasi Pemerintahan dan Politik Orde Baru: Kajian Awal (Government Bureaucracy and New Order Politics: Preliminary Studies). Masyarakat Ilmu Pemerintahan Indonesia (MIPI), Oleh: Yarsif Watampone.

Rondinelli, D., \& Cheema, C. G. (1983). Decentralization and Development, Policy Implementation in Development Countries. London: Sage. 
Schmitter, P. C. (1974). Still the Century of Corporatism? The Review of Politics, 36, 85-131.

Stoker, G. (1991). The Politics of Local Government. London: MacMillan. https://doi.org/10.1007/978-1-349-21516-4

Sudiyat, I. (2010). Asas-Asas Hukum Adat: Bekal Pengantar (Principles of Customary Law: The Introduction). Yogyakarta: Liberty.

Suparman, A. (2012). Position of the Village Head in Indonesia Law. International Journal of Basic and Applied Science, 1, 19-36.

Suroyo, A. M. D. (2000). Eksplorasi Kolonial Abad XIX (Colonial Exploration of the XIX Century). Yogyakarta: Yayasan Untuk Indonesia.

Sutiyo, M., \& Lall, K. (2017). Decentralization and Rural Development in Indonesia. Singapura: Springer Nature.

Syafrudin, H. A., \& Na'a, S. (2010). Republik Desa Pergumulan Hukum Tradisional dan Hukum Modern dalam Desain Otonomi Desa (Village Republic: The Legal Discourse of Traditional Law and Modern Law in the Design of Village Autonomy). Bandung: Alumni.

The Constitution of 1945. The Constitution of the State of Indonesia Republic 1945 (Before the Amendment). Himpunan Peraturan Perundang-undangan Republik Indonesia. Tata Negara-Perdata-Dagang-Pidana. Penerbit Ichtiar Baru Van Hoeve. 2006. 7135.

The Constitution of 1945. The Constitution of the State of Indonesia Republic 1945 (After the Amendment). Himpunan Peraturan Perundang-undangan Republik Indonesia. Tata Negara-Perdata-Dagang-Pidana. Penerbit Ichtiar Baru Van Hoeve. 2006.

Turner, M., \& Hulme, D. (1997). Governance, Administration, and Development. Kumarian Press Inc. https://doi.org/10.1007/978-1-349-25675-4

United Nations (1962). Decentralization for National and Local Development. New York: The United Nations Publisher.

United Nations (2007). Declaration of the Rights on Indigenous Peoples. New York: The United Nations Publisher.

Vollenhoven, C. V. (1907). Law Areas (1907) in Holleman, J.F. ed. (1981). Het Adatrecht van Nederlandsch-Indie (Van Vollehoven on Indonesian Adat Law). Hague: The Hague-Martinus Nijhoff.

Widjaja, H. A. W. (2003). Otonomi Desa Merupakan Otonomi yang Asli, Bulat, dan Utuh (Village Autonomy Is Original Autonomous, Spherical, and Integral). Jakarta: Raja Grafindo Persada.

Yamin, M. (1971). Naskah Persiapan Undang-Undang Dasar 1945 (Preparation Paper of 1945 Constitution). Djakarta: Siguntang. 